\title{
ПРАВОВОЕ РЕГУЛИРОВАНИЕ ФРАНЧАЙЗИНГА В ЯПОНИИ
}

\author{
(C) 2019 Ющенко Наталья Анатольевна \\ кандидат юридических наук, доцент \\ Набережночелнинский институт Казанского федерального университета, \\ Республика Татарстан, Набережные Челны \\ E-mail: yushchenco31@rambler.ru \\ (c) 2019 Хасимова Лейсан Нафисовна \\ кандидат юридических наук, доцент \\ Набережночелнинский институт Казанского федерального университета, \\ Республика Татарстан, Набережные Челны \\ E-mail: hasimov_1@mail.ru \\ (c) 2019 Гайфутдинова Розалия Закиевна \\ кандидат юридических наук, доцент \\ Набережночелнинский институт Казанского федерального университета, \\ Республика Татарстан, Набережные Челны \\ E-mail: rozagayfutdinova@mail.ru
}

В статье представлена система правового регулирования франчайзинговых отношений в Японии. Проанализированы преддоговорные, договорные и постдоговорные отношения сторон. Особое внимание уделяется раскрытию информации до заключения договора франшизы. Авторами определяются условия заключения, изменения и расторжения договора франшизы, их правовые последствия.

Ключевые слова: франчайзинг, франшиза, коммерческая концессия, интеллектуальная собственность, законодательство Японии, международное частное право.

Согласно данным, опубликованным Японской ассоциацией франчайзинга (далее - JFA) за период с апреля 2017 года по март 2018 года число действующих в Японии сетей составило 1339 единиц, включающих 263490 торговых мест и общим оборотом 233 млрд. долларов США [1].

Система нормативно-правового регулирования франчайзинговых отношений в Японии базируется на нормах общего права, таких как Гражданский кодекс Японии [2] (далее - ГК Японии), Закон о содействии торговле товарами среднего и малого бизнеса [3] (далее - MSRCPA), Закон о запрещении частной монополизации и поддержании справедливой торговли [4] (далее - Антимонопольный закон) и правила, разработанные JFA.

Япония относится к странам, в которой отсутствует единый закон, регулирующий франчайзинговые отношения, поэтому не имеется общего определения понятия «франшизы». Тем не менее, есть три соответствующих определения в отношении франчайзингового бизнеса. Bo-первых, MSRCPA регулирует франчайзинг, подпадающий под понятие «бизнес с определенной цепью». Указанный сетевой бизнес определяется как «любой сетевой бизнес, соглашение о котором включает в себя положения, позволяющие его членам использовать определенные торговые марки, торговые наименования или любые другие знаки, и получать за это вознаграждение». Если франчайзинговый бизнес подпадает под это определение, применяются правила MSRCPA. (п. 5 ст. 3, п. 1 ст. 11 MSRCPA).

Во-вторых, в Руководстве, касающемся франчайзинговой системы [1] (далее - Руководство по франчайзингу) в соответствии с Антимонопольным законом, франчайзинговая система обычно считается формой бизнеса, в которой головной офис одновременно предоставляет любому участнику системы, право использовать конкретную торговую марку и торговое наименование и обеспечивает скоординированный контроль, руководство и поддержку его члена и управления им.

B-третьих, JFA определяет франшизу как продолжающиеся отношения между одним 
коммерческим предприятием (франчайзером) и другим коммерческим предприятием (франчайзи), основанные на договоре франшизы. По договору франшизы франчайзер предоставляет франчайзи право использовать товарные знаки франчайзера (логотип, знак обслуживания, торговое наименование и др.), ноу-хау по руководству бизнеса франчайзера для осуществления продажи продукции, а также осуществляет руководство и помощь в организации его бизнеса, а франчайзи выплачивает вознаграждение франчайзеру [1].

В Японии действуют два вида франчайзинга: внутренний и международный. Первый вид франчайзинга, в большей степени, осуществляется путем прямой передачи прав от франчайзера к франчайзи. Для крупных франшизных сетей используется субфранчайзинг. Международные франчайзеры обычно применяют генеральные франшизные соглашения для выхода на японский рынок. Эти соглашения являются предпочтительными, потому что трудно контролировать и управлять повседневной деятельностью франчайзингового бизнеса за пределми Японии. Внутренние бренды передаются франчайзерам либо на основании простого лицензионного соглашения, либо на основании договора франшизы. Это обусловлено том, что японское национальное законодательство в достаточной степени обеспечивает права франчайзера и защиту его интеллектуальной собственности.

Если франчайзинговый бизнес признается сетевым, то на него распространяются норма MSRCPA регулирующие обязательства по раскрытию информации, связанные с предложением и продажей франшиз. Франчайзер обязан предоставить в письменном виде потенциальному франчайзи полное описание франшизы. Документ о раскрытии информации может быть написан на любом языке, дающем возможность франчайзи, ознакомится с его содержанием. Обязательного требования к составлению каких-либо документов или договора франшизы на японском языке, законодательством не предусмотрено.

MSRCPA не закрепляет периодичность раскрытия информации в связи с ее обновлением. Однако подлежит раскрытию информация о франшизе в случае заключения договора субфраншизы. Следовательно, раскрывается содержание основного договора франшизы и отношения между франчайзером и субфранчай- зером. Объем раскрытия информации контролируется Министерством экономики, торговли и промышленности Японии (Ministry of Economy, Trade and Industry), а также иными отраслевыми министерствами. За нарушения обязательств по раскрытию информации, соответствующий государственный орган, может выдать предписание франчайзеру об его устранении (п. 1 ст. 12 MSRCPA). Если франчайзер в установленные сроки не устранит нарушения, этот факт может быть придан гласности через средства массовой информации (п. 2 ст. 12 MSRCPA). MSRCPA не предусматривает каких-либо специальных средств правовой защиты для франчайзи, в случае нарушения требований о раскрытии информации франчайзером. Таким образом, франчайзи осуществляет защиту своих нарушенных прав, основываясь на общих принципах ГК Японии. Например, в случае умышленного сокрытия информации франчайзером, на основании ст. 96 ГК Японии, франчайзи вправе расторгнуть договор франшизы. При неясности условий договора франшизы, такое соглашение может быть признано недействительным в силу ст. 95 ГК Японии. При этом франчайзи вправе подать иск в суд о возмещении убытков, причиненных нарушением о раскрытии информации (ст. 415 и ст. 709 ГК Японии). Обязательным условием возмещения убытков является признание незаконности нарушения о раскрытии информации. Это позволит установить причинно-следственную связь между нарушением и возникшими убытками. Гражданское законодательство Японии не предусматривает правил расчета убытков, следовательно франчайзи должен доказать их размер в суде.

Руководство по франшизе регулирует предложение и продажу франшиз с точки зрения Антимонопольного закона, контроль за соблюдением которого осуществляет Комиссия по справедливой торговле (Japan Fair Trade Commission). В случае нарушения MSRCPA о pacкрытии информации, франчайзи, также может требовать признания нарушения Руководства по франшизе и, следовательно, антимонопольного законодательства Японии.

В соответствии со ст. 11 MSRCPA, франчайзер должен предоставить следующую информацию франчайзи. Во-первых, данные о франчайзеpe, которые включает в себя сведения о компании франчайзера; финансовую отчетность за последние три года; перечень сетевых орга- 
низаций, входящих в систему франчайзинга; ограничения для франчайзи в участии сетевого бизнеса; количество судебных дел по всем договорам франшизы за последние пять лет. Во-вторых, характер и метод финансовых обязательств между франчайзером и франчайзи: сумма первоначального взноса, срок и порядок оплаты, условия возможности ее возврата; порядок и способ оплаты поставляемых товаров для франчайзи; размер и метод расчета периодических выплат; характер иных вознаграждений франчайзеру. В-третьих, условия и объем использования товарного знака, фирменного наименования франчайзера, а также предоставления информации об участии франчайзера в организации бизнеса франчайзи и периодичность осуществления его инструктажа. В-четвертых, информация о договоре франшизы, сроке его действия, расторжения и продления, размер и порядок возмещения убытков и иных компенсационных выплат при прекращении договора.

JFA разработала и приняла добровольные правила, такие как Кодекс этики JFA [5] и Добровольный стандарт в отношении раскрытия и разъяснения информации для потенциальных франчайзи [6], которые обязательны для ее членов.

На договорные франчайзинговые отношения распространяются нормы ГК Японии и Генеральный план этики JFA [7].

В соответствии со ст. 1 ГК Японии существует общая обязанность действовать добросовестно. Если соглашение неоправданно выгодно для одной из сторон, оно может быть признано недействительным, поскольку противоречит установленной государственной политике (ст. 90 ГК Японии). Эти пункты влияют на отношения франшизы по-разному. Обязанность действовать добросовестно в соответствии со ст. 1 ГК Японии порождает обязанность франчайзера раскрывать информацию. Так, суд в одном из дел указал, что франчайзер обязан предоставлять потенциальным франчайзи точную и объективную информацию, чтобы последние могли принять решение о возможности заключения договора франшизы [8]. Статья 90 ГК Японии используется судами для ограничения возмещаемых убытков. Например, в одном из дел, суд заявил, что возмещенные убытки на сумму, равную 60-месячной выплате за лояльность, были в значительной степени несбалансированными с ожидаемой суммой убытков. Следовательно, возмещенные убытки были признаны недействительными в той мере, в которой они превышали разумную сумму убытков, поскольку такая сумма противоречила надлежащему публичному правопорядку [9].

Генеральный план этики JFA предусматривает, во-первых, что товары, услуги или ноу-хау, подлежащие лицензированию, должны опираться на прошлый опыт и результаты деятельности франчайзера. А во-вторых, франчайзер должен предоставить достоверную информацию потенциальным франчайзи, а также не использовать рекламу, вводящую в заблуждение при предоставлении товаров или услуг.

Руководство по франшизе регулирует текущие отношения между франчайзерами и франчайзи, касающиеся ограничений поставщиков, квоты обязательных закупок, объемов продажи товаров по выгодным ценам и внесения изменений в договор франшизы. Если на франчайзи будут установлены ограничения по территории осуществления предпринимательской деятельности, перечня поставщиков и объема закупаемых товаров и услуг, конкуренции и юрисдикции разрешения споров, то они должны соответствовать Руководству по франшизе и Антимонопольному закону. Руководство по франшизе содержит перечень ограничений, которые не допускаются, как противоречащие антимонопольному законодательству и недобросовестной торговой практики. Комиссия по справедливой торговле Японии, может выдать предписание о запрете действия подобных ограничений, их исключении или изменении.

Платежи по договору франшизы устанавливаются соглашением сторон. Однако франчайзи может требовать признания обязательства по внесению платежей недействительными, в случае если считает, что эта сумма является неоправданно высокой. В суде такое обстоятельство может быть истолковано как злоупотребление доминирующим положением при переговорах о заключении договора франшизы и нарушающее обычаи и общественный правопорядок Японии (ст. 19 Антимонопольного закона, ст. 90 ГК Японии). Национальное законодательство Японии не ограничивают возможность франчайзи осуществлять платежи иностранному франчайзеру в его национальной валюте.

Договор франшизы обязательно предусматривает условие о конфиденциальности предоставленной франчайзи информации, которое 
обеспечивается либо наложением судебного запрета, либо возмещением убытков за ее разглашение. Как правило, в договор франшизы включают требование к франчайзи о регулярном предоставлении отчетности и право франчайзера осуществлять проверку деятельности франчайзи.

Права, вытекающие из договора франшизы, могут быть переданы франчайзи по договору субфраншизы полностью или частично только с согласия франчайзера.

Во время действия договора франшизы, франчайзер вправе в одностороннем порядке внести в его условия изменения, относительно осуществления франчайзинга.

Договор франшизы может предусматривать условие о его пролонгации. В таком случае, заключать новый договор не требуется. Если необходимо продлить только срок договора франшизы, то в этом случае заключается либо новый договор, либо дополнительное соглашение к договору франшизы о продлении его срока действия. С одной стороны, в договоре франшизы могут быть предусмотрены условия, при которых франчайзер вправе отказаться от продления отношений с франчайзи. С другой стороны, в случаях, когда в договоре франшизы указано, что он будет продлен автоматически, если ни одна из сторон не сообщит об ином, неясно, при каких обстоятельствах франчайзер может отказаться от его продления. По этому вопросу есть дело, в котором суду потребовались «существенные обстоятельства, доказывающие невозможность продления договора, предусматривающего его автоматическую пролонгацию» [10].

Договор франшизы может быть расторгнут по взаимному соглашению сторон, либо по инициативе франчайзера или франчайзи. Так, на основании ст.ст. 541-543 ГК Японии, договор франшизы может быть расторгнут по инициативе франчайзера, в случае нарушения франчайзи его условий. Обычно в договоре франшизы указываются обстоятельства, при которых франчайзер или франчайзи могут расторгнуть договор франшизы. Поскольку договоры франшизы обычно представляют собой непрерывные долгосрочные отношения, франчайзер или франчайзи могут сослаться на «доктрину утраты взаимного доверия», как основание для расторжения договора, которое применяется в отношении договоров аренды. Во многих случаях эта доктрина применяется или рассматривается судом для ограничения возможности франчайзера прекратить франчайзинговые отношения, даже в случае, если франчайзер ссылается на нарушение франчайзи условий договора. Это означает, что основание расторжения договора франшизы должно носить существенный характер. Законодательство Японии предоставляет больше защиты прав франчайзи при расторжении договора франшизы, объясняя это зависимостью бизнеса франчайзи от отношений франчайзинга.

Условия рассмотрения споров между сторонами по договору франшизы зависят от выбора юрисдикции или вида суда. Различия между судебным и арбитражным разбирательством связано с возможностью апелляционного обжалования, публичностью, выбора языка, судьи или арбитра.

Авторы выражают благодарность Ющенко Снежане Анатольевне за осуществление перевода иностранной литературы.

\section{Библиографический список}

1. Japan Franchise Association. 2020.// http://www.jfa-fc.or.jp/particle/29.html.

2. Civil Code. Act No. 89 of April 27, 1896// http://www.moj.go.jp/content/000056024.pdf.

3. Medium and Small Retail Commerce Promotion: Act Law No. 110 of 1973. // https://elaws.e-gov.go.jp/search/ elawsSearch/elaws_search/lsg0500/detail?lawId=348AC0000000101.

4. Act on Prohibition of Private Monopolisation and Maintenance of Fair Trade: Act No. 54 of 1947. // https://www. jftc.go.jp/dk/guideline/unyoukijun/franchise.html.

5. JFA Code of Ethics. Japan Franchise Association. 2020.// https://www.jfa-fc.or.jp/particle/36.html

6. JFA Voluntary Disclosure Standard. Japan Franchise Association. 2020.// https://www.jfa-fc.or.jp/particle/41.html.

7. JFA ethic general plan. Japan Franchise Association. 2020. // https://www.jfa-fc.or.jp.e.ek.hp.transer.com/ particle/36.html.

8. Hara E. The franchisor-franchisee relationship in Japan. Law Business Research. 2019, 27 August // https://www. lexology.com/library/detail.aspx?g=b1da7e32-4b04-4553-b3a8-d7c58ad33cc5. 
9. Hara E. Domestic and international franchising, master franchising, and regulation of franchise agreements in Japan: overview. 2020. // https://uk.practicallaw.thomsonreuters.com/4-632-3469?transitionType=Default\&con textData $=$ (sc.Default $) \&$ firstPage $=$ true $\& b h c p=1$.

10. Franchise 2011. Contributing editor: Philip F Zeidman. Law Business Research. London. ISSN1752-3338. P.91-96. 